\title{
Welcoming the life of society 5.0 in Indonesian education using soft system methodology
}

\author{
Arif Bagas Adi Satria
}

Societeit de Kata Mata Salatiga

bagas.sathreea02121996@gmail.com

DOI: 10.18326/attarbiyah.v6i1.61-79
Submitted:
Accepted:
Published:
2 March, 2021
8 August, 2021
12 August, 2021

\begin{abstract}
Commemorate the life of Society 5.0 cannot separate from utilization of the latest digital technology. Advanced the education of Indonesia is the duty of the people to become Indonesian nation, that is to enrich the life of the nation. The Education of Indonesia, which has been using for the stream of Western Education namely the class style (bank style), emphasizes tables, chairs and blackboards. We must replace with a more flexible style of education and millennial oriented, no longer rely on an old-fashioned educational methods. Therefore, we need an effort in welcoming life of Society 5.0 with Soft System Methodology utilization. The method used in this study is a descriptive qualitative analysis method with secondary data to describe the phenomena that occur in the field with sufficient and supporting data for this paper. Based on the studies that have carried out, we can conclude that the proper use of the Soft System Methodology can advance Indonesian Education to Welcoming the Society 5.0.
\end{abstract}

Keywords: Education, Society 5.0, Soft System Methodology. 


\section{INTRODUCTION}

Implementing education and learning in schools today shows an alarming condition and is far from expectations. Learning seen by many experts as not being able to teach children with the expected results. Some of the apparent weakness tendencies include that the learning that carried out only leads to the provision of information, tests that simply reproduce the information received, students are passive. This shows that many learning activities (teaching) carried out by teachers do not automatically create student learning activities.

Among the many factors that contribute to the decline in the quality of learning today is the application of learning strategies and methods. Lately, a lot offered up-to-date learning strategies, methods, or models, and schools may simply adopt them. Meanwhile, in other facts, it is also widely revealed that the learning methods used in schools are mostly as lectures, questions and answers, discussions, assignments, and exercises.

The learning strategies and methods that have implemented so far, both those that are traditional and the latest ones, still leave several big questions, because they are incapable of bringing change means in raising the quality of learning. What is even more concerning is that in many design studies, methods traditionally often "sacrificed" when juxtaposed with methods that are up-to-date. With adapted amount up-to-date, modern methods do not even bring about fundamental changes. Learning strategies and methods that are theoretically considered better, when applied in the field, are also not very effective, and even cause additional problems. Not infrequently a method actually makes learning activities more chaotic, students and teachers feel increasingly burdened, infrastructure does not support, and so on. We can observe that there is a gap in using a method between its theoretical validity and its practical ineffectiveness. Of course, many factors have contributed to this gap, and one of the most fundamental is the inconsistency in the application of the basic idea of a method (theory) to a practical level. With this inconsistency, we apply whatever method does not seem to be of much help in improving the quality of our learning. As a result, implementing learning still scavenges and looks for the format of the strategy that is considered the most effective, without realizing what the underlying problem is in the application of the learning methods themselves. 
In the era of the Industrial Revolution 4.0, we have known many application tools that make it easier for us to live our lives, especially if we are intended to welcome the life of Society 5.0. Society 5.0 is a definition born by the Japanese government: A humancentered society that balances economic advancement with the resolution of social problems by as system thaht highly integrates cyberspaces and physical space which means: "A human-centered society that balances progress economy by solving social problems through a system that deeply integrates cyberspace and physical space. " (Cabinet Office Government of Japan). Society 5.0 is proposed in The 5th Science and Technology Basic Plan as a future society that Japan should aspire to, which has been preceded by a hunting society (Society 1.0), an agricultural society (Society 2.0), an industrial society (Society 3.0 ) and an information society (Society 4.0 ).

Society 5.0 achieves a high level of convergence between virtual world (virtual space) and physical space (real world). In the information society (Society 4.0 ), people will access cloud services (databases) in cyberspace via the internet and search, retrieve, and analyze information or data. Society 5.0, people, objects and systems are all connected in cyberspace and the optimal results obtained by AI exceed the capabilities of humans being feed back to physical space.

Society 5.0 can not be separated from the era of the Industrial Revolution 4.0 which affects the layers of community life in the global order. The word "revolution" denotes a sudden and radical change. Throughout human history, revolutions have occurred when the latest technologies and new ways of viewing the world triggered profound changes in the economic system and social structures. Referring to this historical context, the element of urgency of this change still takes years to realize (Schwab, 2016).

In facing welcoming Society 5.0, Indonesian education must be improved again. Advancing Indonesian education is an undoubtedly mandated task for all Indonesian people, as stated in the 1945 Constitution, namely "... educating the nation's life ...". But today, the quality of education in Indonesia is still far behind those of developed countries. According to the Political and Economic Risk Consultant (PERC) survey, the quality of education in Indonesia ranks 12th out of 12 countries in Asia. Indonesia's position is under Vietnam. According to data reported by The World Economic Forum Sweden (2013), Indonesia has low competitiveness, which only ranks 37th out of 57 countries surveyed in the world. Still according to a survey from the same institution. 
Indeed, quantitatively it can be said that education in Indonesia has made progress. The achievement indicator can be seen from the people's reading and writing ability which has reached 67.24\%. (Mulyani, 1999). This is a result of the educational equality program built by the New Order regime, namely SD IMPRES. However, the qualitative success of education in Indonesia has not succeeded in building a smart, creative, let alone superior national character. (Uno, 2007). In other sources, it is true that the current development and condition of Indonesian education, the number of primary and secondary education institutions has continued to increase since the independence era. In 2014 alone, there were 148,061 primary schools, 36,210 secondary schools and 25,580 vocational high schools. Likewise, the number of Indonesian children who have access to primary and secondary education, there are 26,119,000 primary schools, 9,901,000 secondary schools, and 1,735,000 vocational high schools. The number of students in Indonesia has doubled. Indonesian students in 2017 stood at 3,900,000. Indonesia's good performance in several global maps, namely: 1) ranked 30th out of 142 countries in terms of capacity to innovate (equal to New Zealand and better than Spain and Hong Kong); 2) ranked 28th out of 142 countries in terms of wage levels and productivity (on par with Ireland and better than Denmark, Germany and Norway); 3) ranked 51st out of 142 countries in terms of consumer empowerment / conscience (on par with Brazil and better than Russia, Turkey and Brunei); 4) ranked 36th out of 142 countries in terms of favoritism in decision-making (on par with Austria and better than France, Brazil and the United States); 5) ranked 34th out of 142 countries in terms of government spending inefficiency (on par with Taiwan and better than Germany, UK and Israel); and 6) ranked 36th out of 142 countries in terms of government regulatory burden (equivalent to Luxembourg and better than Austria and the Netherlands). But what needs to be paid attention is that $75 \%$ of schools in Indonesia do not meet the minimum education service standards. The low average score of the teacher competency test is 44.5 , whereas the expected standard is 70 , ranking 40 out of 40 countries from the mapping of The Learning Curve - Pearson. Then according to UNESCO, the reading interest of Indonesians in 2012 was 0.001 ( 1 in 1000 Indonesians who have serious intentions to read). (Baswedan, 2014)

Many graduates of formal education institutions, both high school and higher education, seem unable to develop creativity in their lives. High school graduates find it 
difficult to work in the formal sector because their skills are not sufficient, likewise high school graduates who are not vocational (SMK) experience the same problem. For undergraduates, only a small proportion of those who work in the formal sector, most of them have the characteristics of only understanding theory and are weak in practice, motivation to study is only to pass an exam, oriented towards achieving grades or limiting targets, learning orientation only in individual courses, learning process passive, and the use of technology that is separate from learning. (Afifah, 2015). In fact, based on the National Education System Law (UU Sisdiknas) Number 20, 2003, education is a conscious and planned effort to create an atmosphere of learning and the learning process so that students actively develop their potential to have religious spiritual strength, selfcontrol, personality, intelligence, noble character, and skills needed by him, society, nation and state. (UU No. 20 tahun 2003 tentang Sistem Pendidikan Nasional). However, in reality today the lessons in schools are only "bribes" of heavy material and do not give students the opportunity to express themselves totally. Some conventional practices are still carried out by old educators who still use conservative methods, such as mnemonics (memorizing), or collecting facts and information called banking, as if customers keep money in a bank. (Yamin, 2017).

Reflecting on the education developed by Paulo Freire, one of the most influential writers on the theory and practice of critical education of the 20th century, who struggled in education for the oppressed, concocting and marrying educational concepts that are very practical to work on in overcoming ignorance, especially in Brazil (Yamin, 2017: 139), Indonesia should have seen an educational problem plagued by itself through the cultural character of its own country. In the Koran it is explained as follows:

And it is not fitting for all the believers to go (to the battlefield). Why do some of each group among them not go to deepen their religion and to warn their people when they return, so that they can protect themselves. (QS. At-Taubah: 122)

Then reinforced by the following hadith:

Whoever studies a knowledge that is not to seek the pleasure of Allah, but only to obtain material values from worldly life, then he will not smell the fragrance of heaven. (HR. Ahmad, Abu Dawud, and Ibn Majah). 
Education is not only for obtaining material values, but must include sciences that are useful for life, so that critical and creative ways are needed to shape the person into a human who has a character not only in classical and mnemonic ways, but it must also be dynamic and innovative. This is in line with the letter in the Koran as follows:

Read with (mention) the name of your Lord who created. (QS. Al-Alaq: 1)

Verily in the creation of the heavens and the earth, and the alternation of night and day there are signs (the greatness of Allah) for those who are intelligent (i.e.) those who remember Allah while standing, sitting or lying down, and they think about the creation of the heavens and the earth. (While saying), "O our Lord, you did not create all of this in vain; Glory be to You, protect us from the punishment of hell. "(QS. Ali Imran: 190-191).

From the above verse, we can take a lesson that we can "read" all the conditions that have been created in the universe. We can read the whole situation, map some problems to be used as a problem formula, then we solve the problem and we conclude the problem with the relevant theory. Likewise with education, we can innovate with what is already happening in this world as well as possible. The technology that has been created is also a human creation that can be used as efficiently as possible.

Therefore, a real action is needed that is fast in dealing with these problems through reading the opportunities of technological advances in Society 5.0. Optimizing all aspects that have been felt from the latest digital technology developments can be a "weapon" to create a bright education in the future.

\section{METHOD}

This research is a qualitative research. The research method used in this study is a literature review of various studies that have been researched and reviewed previously. The data collection method used is secondary data obtained from journals, books, documentation, and the internet. In addition, data that has been published by institutions with reliable credibility are also used, such as data from the Ministry of Education and Culture, and other credible institutions. Qualitative research is the research which intends to understand the phenomenon of what is experienced by research subjects, for example: behavior, perception, motivation, action, and others, holistically and by way of description in the form of words and language, in a specific context which is natural and with take advantage of various natural methods. (Moleong, 2013) 
The method of data analysis in this study was carried out by descriptive analysis method, namely the data obtained and analyzed by the descriptive analysis method. Descriptive analysis method is carried out by compiling the data obtained then interpreted and analyzed so that it can provide information for solving the problem at hand.

\section{RESULT AND DISCUSSION \\ Utilization of Soft System Methodology in Education}

In today's educational situation which has entered the era of disruption, we should not be wary and creative to bring innovative learning and ensure the National Education Standards can be achieved. According to Ristekdikti in Risdianto (2019), the era of disruption can be explained through VUCA, namely massive, fast changes, with unpredictable patterns (Volatility), rapid changes that can cause uncertainty (Uncertainly), the occurrence of complex relationships between the factors causing change (Complexity), and lack of clarity in the direction of change that causes change. ambiguity (Ambiguity). The government's policy in providing education in the Industrial Revolution 4.0 is implementing strategic steps that have been determined based on the road map for Making Indonesia 4.0. This effort was made to accelerate the realization of the national vision that had been set to take advantage of opportunities in the era of the Fourth Industrial Revolution. According to Hartanto Risdianto (2019), Indonesia plans to overhaul the education curriculum with more emphasis on STEAM (Science, Technology, Engineering, the Arts, dan Mathematics), aligning the national education curriculum with industry needs in the future. Indonesia will work together with industry players and foreign governments to improve the quality of vocational schools, as well as improve the workforce mobility program for global labor mobility to take advantage of the availability of human resources to accelerate the transfer of skills.

Not only participants, but teachers and lecturers must be prepared to face these skills. In their function in learning interactions, teachers and lecturers must be able to build an atmosphere that can meet the psychological needs of students, which include: needs for competence (every student needs to feel able), needs for autonomy (every student needs to feel autonomy / freedom and trust), and needs for relatedness (every 
student needs a group). Learning in the era of disruption must be able to provide sustainable learning capabilities, so that students / learners can go through this era of disruption and enter a new era called the Abundant Era, an era that is abundant, especially in information, media and learning resources. Risdianto (2019). To achieve 21st Century Skills, learning trends and best practices must also be adjusted, one of which is through integrated learning or by blended learning. Blended learning is a way of integrating the use of technology in learning that enables appropriate learning for each student in the classroom, which allows learning to occur. This is in accordance with the Soft System Methodology described above. In addition, learning that must be absorbed into the era of the Industrial Revolution 4.0 which is disruptive in nature is self-directed (a learning process that occurs because of the perceived needs of students), multi-sources (using various sources, media, and learning channels), long-life learning, and ICT base (learning using information technology).

Some of the ways that education in Indonesia can do to face Society 5.0, namely:

1. In terms of infrastructure, the government must strive to increase equitable development and expansion of internet connections to all regions of Indonesia, because as we know today, not all areas of Indonesia are currently connected to an internet connection.

2. In terms of human resources, who act as teachers must have skills in the digital field and think creatively.

3. The government must be able to synchronize education and industry so that later graduates from universities and schools can work in accordance with their fields and in accordance with the criteria required by the industry so that later they can reduce the unemployment rate in Indonesia.

4. Applying technology as a tool for teaching and learning activities. (Nastiti, 2020).

According to the Minister of Research, Technology and Higher Education (Menristekdikti), Muhammad Nasir, explained that there are four things that should be the attention of universities to produce graduates with high quality and competence, namely:

1. Competency-based education is one of the main missions of higher education in the present era. Every student has their own talents and abilities, therefore an information technology approach is needed to help determine the right study program according to their abilities. 
2. Utilization of IoT (Internet of Things) in education. With the IoT, it can help communication between lecturers and students in the teaching and learning process.

3. Utilization of virtual / augmented reality in education. Using augmented reality can help students understand theories that require certain simulations according to actual conditions. 3D technology in augmented reality makes the wearer feel a digital simulation, just like a real physical activity.

4. The use of artificial intelligence (AI) in the world of education to identify and identify learning needs that are being needed by students. The process of identifying student needs will be faster with machine learning technology embedded in artificial intelligence. (Nastiti, 2020).

The phenomenon of implementing learning in our schools shows haphazard practice, the origin of the road, monotonous, and not based on awareness based on theories and paradigms. In our schools in several years and even decades, the strategies used are near to the lecture method, question and answer, discussion, and assignment (assigning). With the downturn in education that is felt by many parties, conventional expository-based learning methods considered (and blamed) as the cause. These methods have widely criticized and considered being completely wrong methods or approaches. As an approach to learning strategies, both lectures, questions and answers, and discussions, of course, each of them has characteristics as strengths and weaknesses (Surachmad, 1986). Researcher base it methods on philosophies, paradigms, theories, models, to a more detailed technical level. The strategy (method) of course has various potentials.

In the situation and condition of children and schools in Indonesia, where facilities and infrastructure are limited and human resources to the existing climate, methods such as lectures, question and answer, or discussions are not impossible methods. Which is still workable. At least, in reality in education implementers remain these methods as the crucial choices. The problem is how the method applied in learning in schools. Often a teacher carries out learning without being based on a convincing plan of what method to use. The orientation is only mastery of the subject. As a result, in learning activities the teacher tries to spend the material that has prepared without realizing how the activities of students learn when receiving the subject. 
The most common example is the use of the lecture method. In the lecture method used, the teacher ignores whether a speech or a presentation; whether problem oriented, idea oriented, or a body of knowledge oriented, including how to lecture well. In fact, with good planning and the stages are consistently and calculatedly heeded, the lecture method could be an effective method, likewise for the other methods. So, the fundamental problem related to the use of this learning method is the lack of seriousness in applying a method. This may be because of the teacher's ignorance of the method used, the assumption that the method can be carry out even without preparation, because according to existing habits, the reluctance to reflect on the methods that have carried out so far, do not want to be bothered with the procedures used detail, and low motivation to improve performance. It is reasonable to suspect that the implementation of learning patterns and strategies which have been overall less positively correlated with improving the quality of student learning, is caused by the imperfect and optimal application of learning strategies in accordance with the procedures and techniques desired from the basic idea of a strategy and learning method.

Progress in as a first step towards realizing Society 5.0, if you read the situation correctly, it can be used as an opportunity to build Indonesian education towards education that is enlightening and represents a revolutionary education, by applying a methodology called Soft System Methodology. Soft System Methodology was specifically developed in the 1970's to cope with normal situations in which people have their own perception of the world by making judgments using their own values." (Attefalk \& Langervik, 2001). Peter Checkland in Widjajani (2001) provides some key thoughts that form the basis of Soft System Methodology, namely:

1. In thinking about real-world systems that need improvement, it is humane for people to try to carry out purposed activities that benefit them. This led to the idea of modeling a purposed human activity system as a collection of related activities that could show the emergent characteristics of the goal.

2. In an effort to model objective activities, an exploration of actions in the real world is carried out. This exploration turned out to produce many possible interpretations for each target statement. For this, first we have to choose the most relevant interpretation in exploring the situation, depending on the point of view (world view or weltanschauung) which is the basis of the model. 
3. The point of view is the result of the learning process (learning process). The learning here that makes the idea of modeling a purposeful activity is a useful concept. Therefore, the modeling process here can be seen as an inquiring process.

The process of building activity models aims to include the selection of relevant systems that take part in the objective action of the problem situation. From the selected human activity system, a number of models are built based on different worldviews. These different viewpoints are expressed with clear definitions of the activities being modeled and are called root definitions. The root definition is built as an expression of activity aimed as a message of transformation. According to Peter Checkland, every objective activity can be expressed in the form: "an entity, an input in the transformation process, changes into a different state or form, so that it becomes the output of the process. (Widjajani, 2001). As a guideline for creating a root definition, Checkland presents a "CATWOE" mnemonic, namely:

1. C : The Customers of systems reffering to the internet groups who are the benefieciaries or victims and / or without the system and who are affected by the systems activities

2. A : The Actors within the system who carry out or cause to be carried out the main activities of the system

3. $\mathrm{T}$ : The Transformation process by which the inputs to the system are transferred into defined outputs

4. W : The Weltanschauung or persective from which the root definition is seen.

5. O : The Owners of the system who have the ultimate power to cause the system to cease to exist.

6. E : The Environmental constrains on the system that to a large extent has to be taken as "given" and difficult to influence, affect and change (Simonsen, 1994).

The conceptual model is a system model of human activities which consists of elements which are activities and is obtained by extracting all the verbs implied by the root definition. As stated by Avison \& Ftizgerald, Checkland \& Scholes, Checkland \& Tsouvalis and Wilson in Attefalk \& Langervik as follows:

The conceptual model is model of the human activity systems and as such, its elements are activities that can be found by extracting all the verbs they are implied by the root definition. The list of verbs should be arranged in a coherent order and for each root definition, there must be one model. By assembling $7 \pm 2$ activities structured according to logical depredency, the system can be modeled as a whole entitiy. The reason for this number being the suggestion made by Miller, that the human brain only has a capacity to cope with this amount of 
concepts simultaneously. All activities in the model can become a source of a root definition to be expanded at the next resolution level. The purpose of the conceptual model is to accomplish what has been defined in the root definition. Thus, the conceptual model is a model of the root definition and not a model of anything else. (Attefalk and Langervik, 2001).

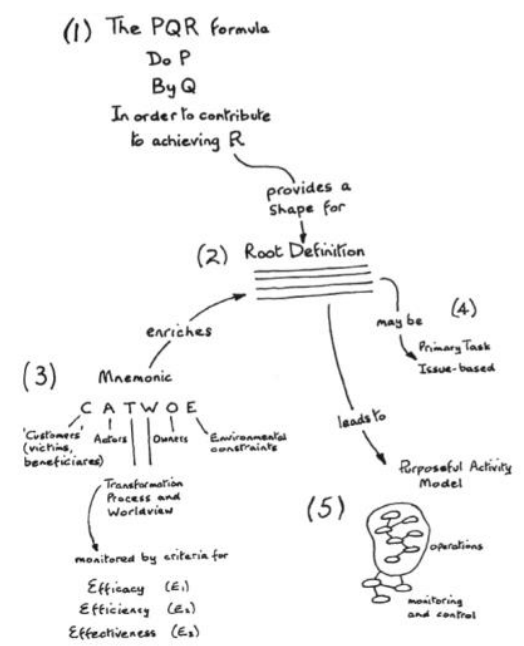

Source: Peter Checkland and John Poulter, from Martin

Reynolds and Sue Holwell, Systems Approaches to Managing Change:

Apractical Guides, London, Springer, 2010, 220.

Figure 1. Helper Guide with Building Model of Purposeful Activities

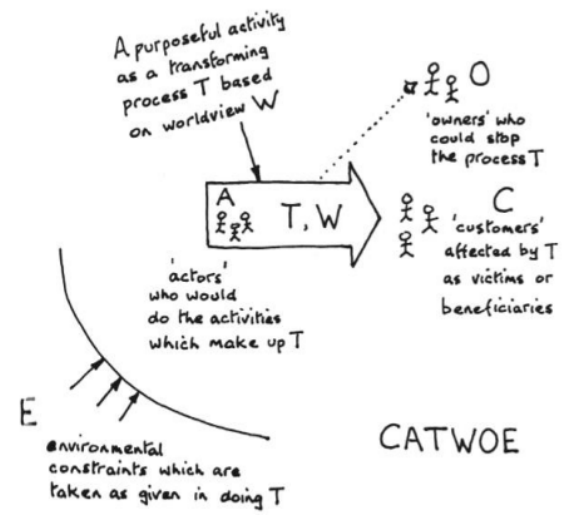

Source: Peter Checkland and John Poulter, from Martin Reynolds and Sue Holwell, Systems Approaches to Managing Change: A Practical Guides, London, Springer, 2010, 221. 


\section{Figure 2. General Model of Various Purposeful Activities, with the results of The Mnemonic CATWOE}

Soft System Methodology is an organized way of dealing with (social) situations that are considered problematic. It is action oriented. It organizes thinking about the situation so that action can be taken to bring about improvement. The complexity of problematic situations in real life stems from the fact that they are not only never static, but also contain many interacting perceptions of "reality". All problematic situations with different world views share a second important characteristic. They always contain people who try to act on purpose, with intent, not just acting on instinct or randomly messing around although there are always many such things in human affairs too.

The two points previously explained, namely the existence of conflicting world views and the emergence of purposeful actions everywhere, direct the way to deal with problematic situations. They support the Soft Systems Methodology approach, a process of inquiry through social learning, working to take "action to improve", taking the following forms:

1. Find out about the problematic situation and the characteristics of the intervention to correct it: the problem, the prevailing culture, and the disposition of power in the overall (political) situation. Means of doing this must be provided.

2. From finding out, decide on some relevant purposeful activities to explore the situation in depth, remembering that the end goal is to define and take "action to improve". Express these relevant purposeful activities as model activities, each created to encapsulate a declared world view, the model is a set of related activities that together form a purposeful whole (For example, one model may express in activity terms the meaning of "prison" as if - if only the "system of punishment", others can express it as "the system of rehabilitation"). Such models never describe the real world, simply because they are based on one pure world view. They are devices, or tools, to explore it in an organized way. Techniques for building and using these models have been developed.

3. Use the model as a source of statements to ask about the situation in this world. It provides a coherent structure for discussion or debate about the situation and how it can be changed, a discussion that will give rise to a world view and generate ideas for change and improvement.

4. During the discussion, continually collect "finding out" results (process no. 1), and ideas for change (process \# 3). The aim now is to find changes that are both desirable (given this model) but also culturally appropriate for these people in special 
situations, particularly historical, cultural and political. It is a process of finding accommodation between different world views. That is, it is a process of finding a version of a situation that has to be changed that can be done by people with different world views that are conflicted and still live together. (Don't expect worldviews to go away or they will. Contradictory world views, ever present in human affairs, stimulate energy and ideas for change.

5. The elements (1) to (4) above constitute a learning cycle. They must be described linearly here but in use there are many iterations (repetitions) in the cycle in which learning occurs. It has never been followed flatly. Basically it is a group process that leads to group learning. It is best done by people in the problematic situation themselves, not left to outside "experts," although someone more experienced can facilitate the process.

6. Taking action to remedy a problematic situation will automatically change the situation so that the learning cycle can in principle be restarted. However, changing the flow of everyday life will automatically bring about new events and new ideas, so that no human situation can be made static. In this sense, the Soft System Methodology learning cycle can be seen as a never-ending. Ultimately it offers a way to continue to manage any ongoing human situation. It does this by helping to understand complex situations, encouraging multiple perspectives to be considered, and bringing rigor to the process of analyzing, debating, and taking "action to improve”. (Reynolds and Holwell, 2010).

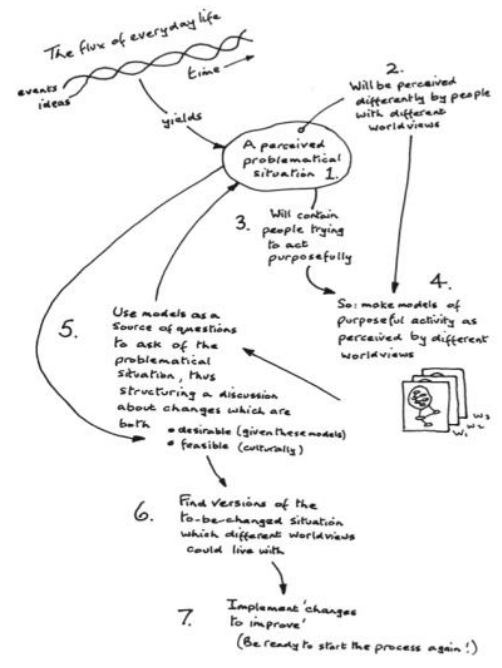

Source: Peter Checkland and John Poulter, from Martin Reynolds and Sue Holwell, Systems Approaches to Managing Change:

A Practical Guides, London, Springer, 2010, 194.

Figure 3. Soft System Methodology Learning Cycle 
Soft System Methodology made based on research originating from natural sciences; create a hypothesis and then test it experimentally. Soft System Methodology is developed using an alternative research model, another method suitable for "social" research at the situation, group, or organizational level, namely "action research". In the action research that produced Soft System Methodology, the initial declared framework was the Systems Engineering approach developed by the Bell Telephone Company from their own case history. The System Engineering is the process of naming a "system" (assuming some complex object that exists or can exist in the real world), determining its purpose, and then using a variety of different techniques. Developed in 1950-the late 1960s and 1960s to "engineer" systems to meet their goals. (Reynolds and Holwell, 2010)

The framework of The System Engineering has been modified (and enriched) according to and in direct response to real-life experiences (reality). Finally, the initiator has a fairly rich framework but is far from the starting point of The System Engineering. This is known as the Soft System Methodology. It took some time even for its pioneers to realize how radical the shift from The System Engineering to Soft Systems Methodology was. After introducing the idea of a world view - essential for dealing with human social complexity - the initiators then thought of a systems model not as a description of something in the real world but only as a tool (based on a world view) to organize the debate about "change brings improvement". This is a key step in finding a pathway to Soft Systems Methodology. This important shift in thinking is not abstruse, but it turns out to be very difficult for many to understand, simply because everyone is familiar with the colloquial use of the word "system". In casual speech, we constantly mention complex chunks of the everyday world as systems, even though they don't come close to the requirements of the concept. We can see examples of the application of the "education system", "health care system", "prison system", and so on. The use of the word "system" is only to denote / show a piece of reality that seems very complex but in a biased / vague sense, as a whole, something that might be better "fabricated". but it turns out to be very difficult for many people to understand, simply because everyone is familiar with the colloquial usage of the word "system". 


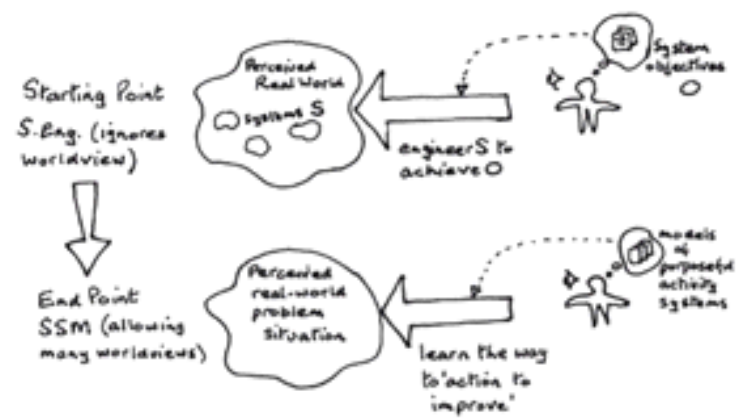

Source: Peter Checkland and John Poulter, from Martin Reynolds and Sue Holwell, Systems Approaches to Managing Change:

A Practical Guides, London, Springer, 2010, 197.

Figure 4. Shifts Required in Developing a Soft System Methodology

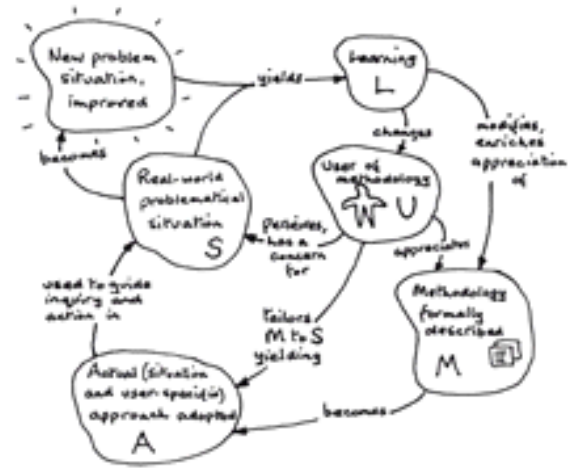

Source: Peter Checkland and John Poulter, from Martin Reynolds and Sue Holwell, Systems Approaches to Managing Change:

A Practical Guides, London, Springer, 2010, 198.

Figure 5. LUMAS Model, Learning For Users with a Methodically Informed Approach to Certain Situations

The Soft System Methodology process is actually a cycle. If used appropriately, it is a learning cycle starting from finding out about a problem situation to determining / taking action to fix it (defining / taking action to improve it). The learning that occurs is social learning from the group that carries out learning, even though the learning of each individual to a greater or lesser degree, is personal to them because they have different experiences in the world, and therefore they will bring different world views to learning. Taking action as a result of the study will of course change the initial situation into a new situation, so that in principle the cycle can be restarted. (Reynolds and Holwell, 2010) 


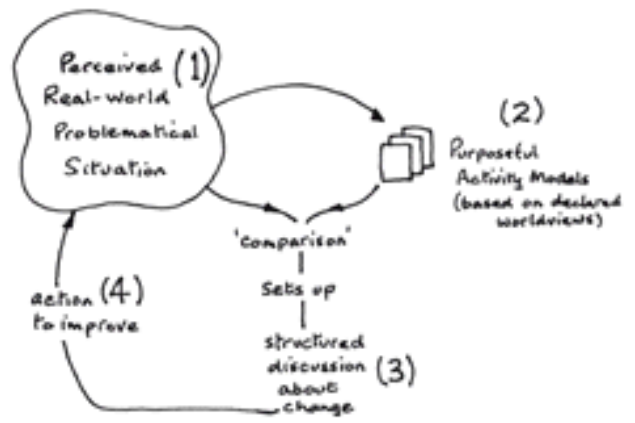

Source: Peter Checkland and John Poulter, from Martin Reynolds and Sue Holwell, Systems Approaches to Managing Change:

A Practical Guides, London, Springer, 2010, 207.

Figure 6. Iconic Representation of the Soft System

Methodology Learning Cycle

The learning cycle applied in the Soft System Methodology contains four types of activities, namely:

1. Finding out about the initial situation which is seen as problematical (finding out about the initial situation which is seen as problematical).

2. Make several models of activities that have goals that are considered relevant to the situation; each model as an intellectual device, which is built on the basis of a particular world view (making some purposeful activity models judged to be relevant to the situation; each model as an intellectual device, being built on the basis of a particular pure worldview).

3. Using models to question real situations. This brings structure to the discussion of the situation, the aim of the discussion is to find changes that are arguably desirable, and which are also culturally appropriate in this particular situation (using the models to question to the real situation).

4. Define / take action to improve the situation (define / take the action to improve the situation).

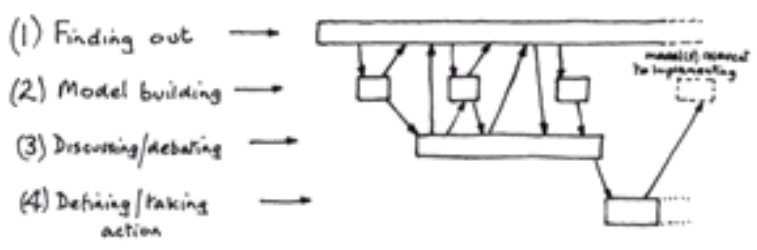


Source: Peter Checkland and John Poulter, from Martin Reynolds and Sue Holwell, Systems Approaches to Managing Change:

A Practical Guides, London, Springer, 2010, 208.

Figure 7. Typical Patterns of Soft System Methodology Learning Activities

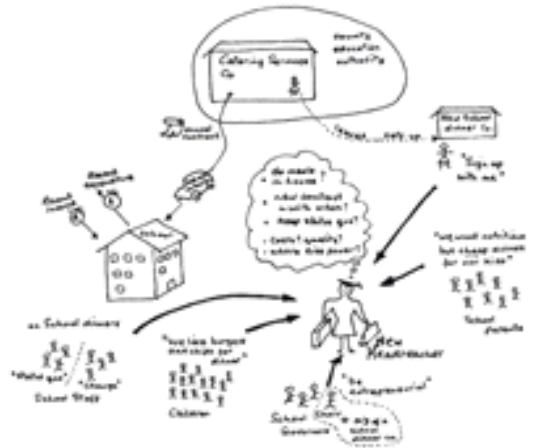

Source: Peter Checkland and John Poulter, from Martin Reynolds and Sue Holwell, Systems Approaches to Managing Change:

A Practical Guides, London, Springer, 2010, 210.

Figure 8. A Rich Pictures to Describe Situations in Text

In the Soft System Methodology learning cycle, there is a familiar method known as Finding Out, which in the language of Soft System Methodology is known as "Making Rich Pictures". Entering a real situation to understand the situation and then turning it towards "improvement", requires a certain frame of mind in using theSoft System Methodology.

\section{CONCLUSION}

The proper use of Soft System Methodology can advance Indonesia's to welcome Society 5.0. By changing and updating Indonesian education methodologies to suit today's social situation, Soft System Methodology can solve educational problems that occur in Indonesia. By looking at the learning cycle that can pay attention to the existing social situation, SSM is very appropriate to be used in Indonesia's urgent educational needs. 


\section{REFERENCES}

Afifah, N. (2015). Problematika Pendidikan di Indonesia (Telaah dari Aspek Pembelajaran)..Jurnal Elementary, I (1), 41-47.

Attefalk, L \& Langervik, G. (2001). Sociotechnical Soft System Methodology; a sociotechnical approach to Soft Systems Methodology. Germany: University of Gothenburg.

Baswedan, AR. (2004). "Gawat Darurat Pendidikan di Indonesia", This paper was presented during a Ministry Meeting with Heads of Services in Jakarta on December 1.

Cabinet Ofifice Government of Japan. (2020). Society 5.0, access at www8.cao.go.jp/cstp/English/society5.0/index.html pada tanggal 15 Oktober at 21.50 .

Mulyani, A.N. (1999). Pokok-Pokok Pikiran Mengenai Implikasi Pelaksanaan UU No. 22 dan 25 Tahun 1999. Paper presented in a workshop at UNY.

Nastiti, FE \& Abdu, A.R.N (2020). Kesiapan Pendidikan Indonesia Menghadapi Era Society 5.0. Edcomtech: Jurnal Kajian Teknologi Pendidikan, 5 (1). 61-66. DOI: http://dx.doi.org/10.17977/ um039v5i12020p061

Reynolds, M \& Holwell, S. (Eds.). (2010). Systems Approaches to Managing Change: A Practical Guides. London: Springer.

Risdianto, E. (2019). Analisis Pendidikan di Era Revolusi Industri 4.0, Bengkulu: Universitas Bengkulu.

Schwab, K. (2016). The Fourth Industrial Revolution. Diena, Farah \& Targian, Andi. Revolusi Industri Keempat. Jakarta: Gramedia.

Simonsen, J. (1994). Soft System Methodology: An Introduction. Rosklide University, Spring.

Surachmad, W. (1986) . Pengantar Interaksi Mengajar-Belajar: Dasar dan Teknik Metodologi Pengajaran. Bandung: Tarsito.

Undang-Undang No. 20 Tahun 2003 Tentang Sistem Pendidikan Nasional.

Uno, HB. (2007). Profesi Kependidikan, Problematika, Solusi, dan Reformasi Pendidikan di Indonesia. Jakarta: Bumi Aksara.

Widjajani. (2011). Penggunaan Soft System Methodology Dalam Penelitian Proses Sosial. Jurnal Sosiohumanitas, XIII (2), 190-221.

Yamin, M. (2017). Menggugat Pendidikan Indonesia: Belajar Paulo Freire dan Ki Hajar Dewantara. Jogjakarta: Ar-Ruzz Media. 